\title{
The Uses of Historic Space in Europe: Local Context versus Globalization
}

IVOR SAMUELS

Ivor Samuels is an architect, planner, Honorary Senior Fellow of the Urban Morphology Research Group,

Birmingham, and a consultant to the UK Civic Trust Regeneration Unit,

England. He was the chair of the Joint Center for Urban Design, Oxford Brookes University. He is a co-author of Urban Forms: The Death and Life of Urban Block (Elsevier /Architectural Press, 2004).

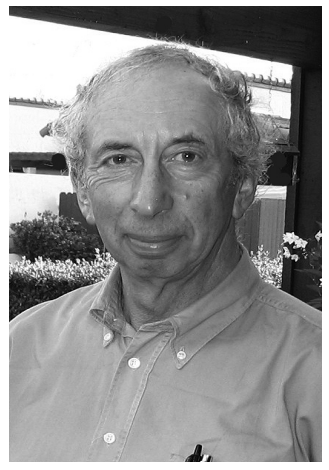

Figure 1

Metz, France. The plan shows how, a 16th century cathedral was used simultaneously for storage, a prison, and a hospital. Although we consider the medieval cathedral to be dedicated to worship it has often been re-used for a variety of functions.
This paper introduces us to an interesting discussion on the impacts of globalization on European historic spaces. The author points out some of the problems in trying to impose trendy design solutions such as new urbanism. Ivor Samuels, is a visiting professor of urban design at the CRP department (Spring 2007).

Against a background where 'everywhere is becoming like everywhere else', this paper attempts an overview of the current situation of historic space in Western Europe as it confronts the challenges of globalisation. It also attempts to widen the discussion by considering, in addition to the range of actual spaces which we might consider historic, the impact that the qualities of these spaces are having on current design activity.

\section{Supply, demand and cultural constraints}

In a general sense the impact of changes in the world economy is only speeding up the process of evolution, which has always occurred to our inherited built forms. Most buildings were erected to serve a purpose; otherwise no one would bother to build them. These buildings, by definition, are static, the only constant in life is change, so that, sooner or later, the needs which these buildings have to meet will change. Even the great Gothic cathedral churches of western Europe that seem to be eternal were used as builders' yards or prisons in XVIII century revolutionary Europe (Figure 1).

Until recently this did not matter; things changed slowly, and building structures could be adapted - witness the 18th century domestic buildings of London, which are now used for universities, offices, libraries and apartments. Since then, buildings have become more specialized and their useful life has also been reduced. Normally, offices last ten years, factories eight years, and shops only five years.

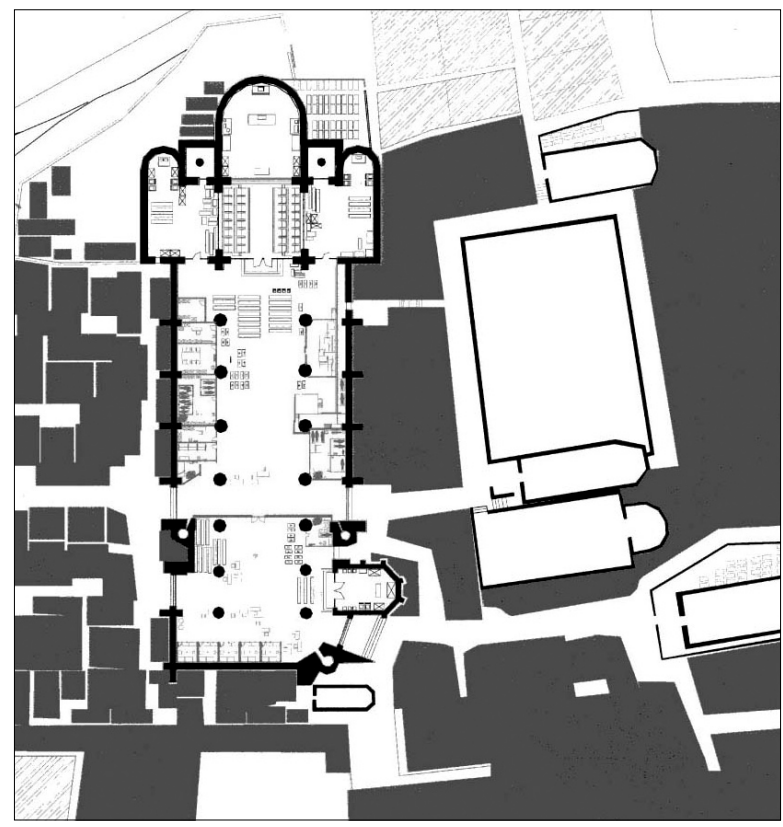

With the exception of some Modern Movement buildings, which are discussed below, the emotional attachment to a building is much more long-lasting than its functional viability. The latter depends on the matching of the supply, represented by a building's characteristics and the extent to which it is protected, to the demand of the market and the social context. This usually means that if we want to keep a building, then the economic and functional demands on it have to be modified.

The extent to which buildings can be conserved is influenced by the roles and power of the different actors in the process of urban change. This can be represented by a range of conflicts (after Couch 1990): 
- Local needs versus National interest

- Property investment versus Local social housing needs

- Tourism versus Local residents

- Preservation versus Functional performance

- Townscape role versus Fabric obsolescence

The relative significance of these factors will, of course, change for different contexts. The impact of globalization has been widely discussed in current literature, and here it will be restricted to its impact on the inherited urban space at different scales. International firms increasingly dominate the urban economy,although the extent to which this results in a homogenization of forms can be exaggerated. For example, in Taipei one can find two international firms $B$ and $Q$ and Carrefour not side by side in a large parking lot as in Europe, but on top of one another! These changes, together with local shifts in the activity patterns, have resulted in changes at different scales from cities and districts to individual buildings. This paper will emphasize the former.

Different types of location can be discussed in terms of several factors, which depend on the area characteristics, the building attributes and condition, and the market and regulatory context. In summary these are:

- The instigators of development

- Commercial emphasis

- Type of image generated

- Social and spatial outcomes

Figure 2

Glasgow, Scotland.

Along the River

Clyde, the once abandoned docks are being revitalized with new uses such as the Science Center, the Imax, and the Moathouse Hotel (all in the center of the photo; from Google Earth). with an emphasis on gearing, for example, the amount of private capital that can be attracted by public investment. A second spectacular example is the Ruhr, the German industrial heartland that was reconstructed after the war and is now undergoing a massive conversion through a large public investment (Schafer 1999) (Figure 3).

The outcomes are large spaces used for new cultural activities, public spectacles, exhibition centersand, art galleries, together with housing for higher income groups, which propose an image of a new urban lifestyle. Any commercial activity is linked to recreation and, sometimes, to heritage tourism.

\section{City Centers}

Conservation of the buildings and the urban fabric of city centers do not mean their preservation like flies in amber, but their adaptation and reuse while retaining their essential

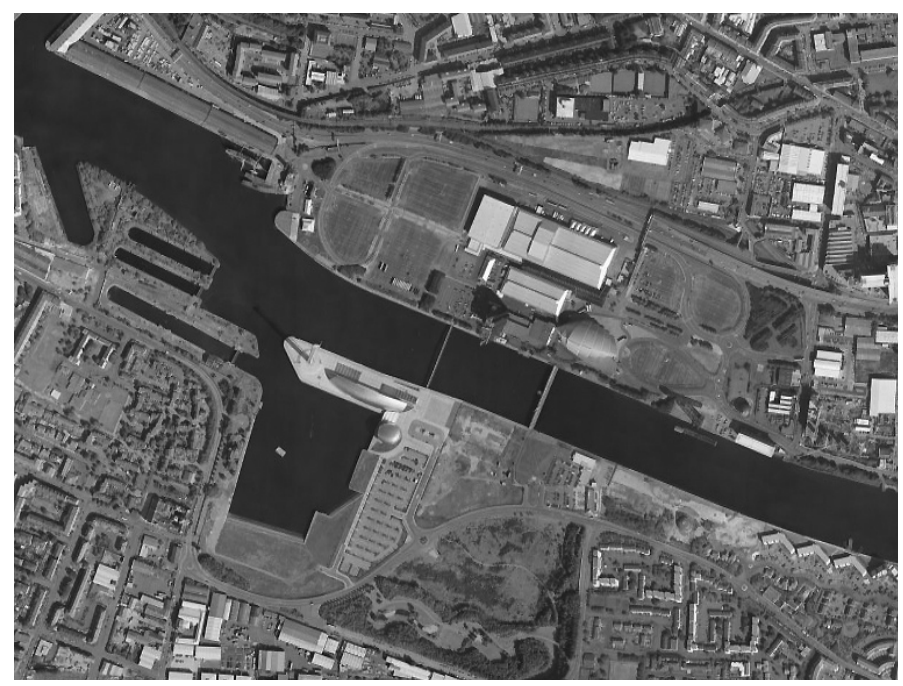




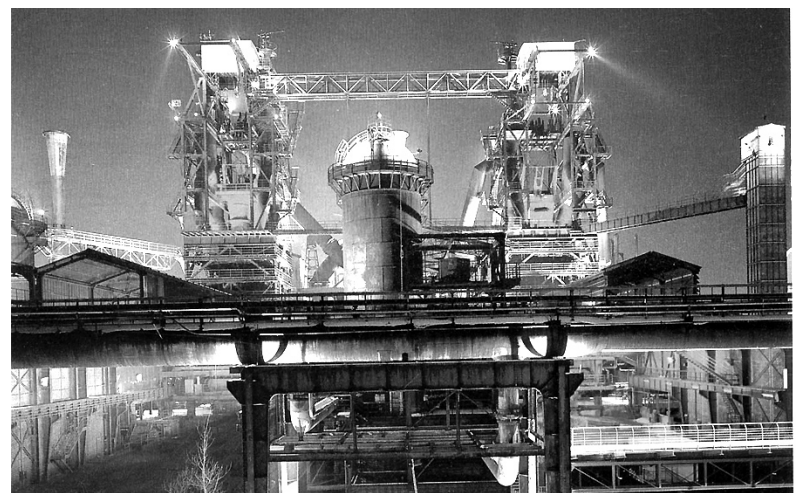

Figure 3

Duisburg, Germany. A former steel works in the Ruhr Valley is used to house major events; here it is illuminated for a rock concert.

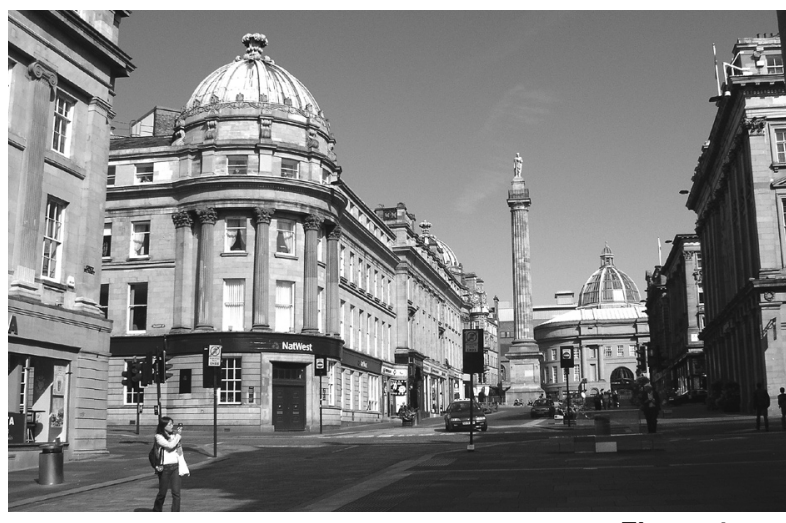

Figure 4 Newcastle, England. The once derelict early 19th century Grainger Town has been revived with new apartments, retail units and offices.

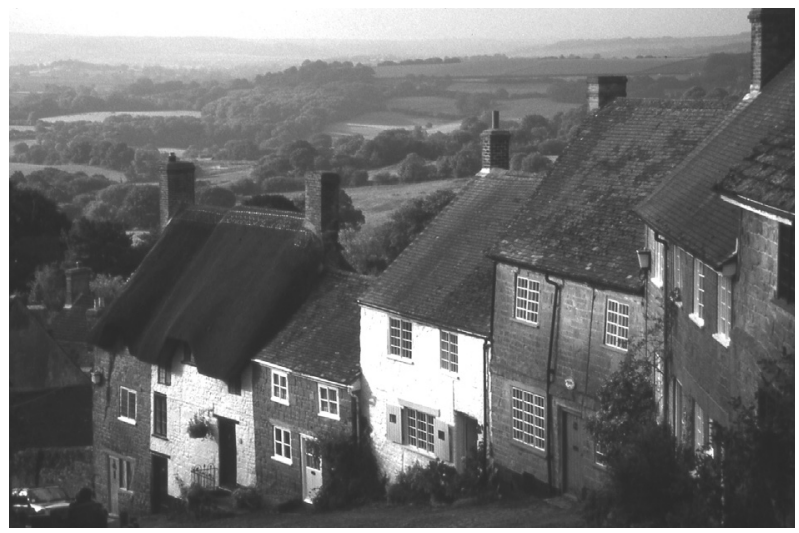

Figure 5

Sherborne, England. A small country town which embodies all the qualities of an ideal place to live - the English equivalent of the US New Urbanism model. properties. In the same way, the conservation of the social and economic life of a city does not mean the propping up of economic activities, which, in this era of globalization, may have shifted to other countries. Other activities must be promoted which allow the life of the town to continue. Cities like Newcastle, which have undergone remarkable changes in their economic fortune, are trying to reinvent themselves thorough the exploitation of their inheritance. Again, the activity has to be started by the public authority in partnership with private business interests to sell the City Center and most notably the area known as Grainger Town (Figure 4), as a destination for local and national visitors through an emphasis on financial office activities, expensive retailing and the 'evening economy.'

\section{Small Towns}

The pressures on small towns are familiar in most developed countries. The first comes from the transformation of the rural economy. Even the bucolic image of la France profonde, with its vineyards and pastures, screens considerable change. The number of those considered to be peasants declined by $38 \%$ in the decade between 1989 and 1999 as industrial agriculture, which employs fewer people and does not depend on local towns, became the norm.

The second factor is the process of decentralization, which has seen retail activity shift from town centers to supermarkets (Figure 4). At the same time that shopping has been decentralized, public facilities have been centralized, again to the detriment of small town vitality. In the pursuit of economies of scale, schools, colleges, hospitals and clinics have been amalgamated into fewer, but bigger units. As a result, these have often needed larger sites in the bigger towns with the local units being shut down. Police stations have also been centralized and the removal of a local presence has increased crime response times and has led to greater rural insecurity (ODPM 2005). All these changes have resulted in a vicious circle of reduced local employment possibilities, lower spending power, reduced provision and, therefore, redundant buildings.

The distinctive character clearly depends on the form of the buildings and their relation with the natural environment, but it can equally derive from the particular economic patterns and the social fabric of the town (Action for Market Towns 2005). Although few of these towns are of exceptional artistic quality, most of them include some protected zones and buildings, and the quality of their built environment and natural settings 
represent an important resource for their economic future as attractive places to live and for tourism (Figure 5).

\section{Modern Movement artifacts}

The buildings constructed in the first six decades of the last century in Europe represent a particular type of inheritance with its own set of unique characteristics that are worth discussing. Modern buildings were innovative in technical, social or aesthetic intentions. Some like the Bexhill Pavilion (architects Chermayeff and Mendelssohn), which gave an identity to an otherwise nondescript seaside town, has all three qualities. Finished in 1935, this building is listed as Grade 1, which means that it enjoys the same protection as the most significant national monuments such as the Tower of London. The problem with many modern buildings is that their aesthetics were in advance of their building techniques. They are more susceptible to the ravages of time than older building so that they often have to be virtually rebuilt just as any ancient structure.

The paradox is that we are now preserving as heritage the 'throw away' buildings of an epoch that rejected all connections with the past. There is also the problem of the general public's dislike for much modern building. In fact, much of the housing stock built in the 1950s and 1960s is now being demolished, but some of it has been conserved. Some buildings now enjoy statutory protection, which, if proposed now, would be rejected because of the way they abusively intrude into a historic context. Embassy court, a modernist building of the 1930s on the historic Regency seafront of Brighton, is a spectacular example (Figure 6). Sometimes the problem is how to modify housing built in the 1960s. The building may be intensely unpopular with the people who have to live in it, but since it is considered to be of cultural significance, it therefore, has been protected. Park Hill in Sheffield (Sheffield 2005) is the most prominent example (Figure 7).

\section{The influence of history- neo-vernacular and the quest for local identity}

Finally, in considering the uses of historic space and forms, we cannot ignore how important they have become over the last decade, especially in the search for a reaffirmation of local identity which has been one consequence of globalization. It is no coincidence that the challenge to the design hegemony of the Modern Movement almost exactly matches the rise of interest in conservation. In the UK, the Act of Parliament, which designated conservation areas, was passed in 1967. In France, a similar law dates from 1963, while the infamous collapse of the Ronan Point block of flats in 1968 heralded the real end of the extensive program of post-war rebuilding according to Modernist principles.

The return to classical principles found its champion in the Prince of Wales and through his patronage the town extension of Dorchester

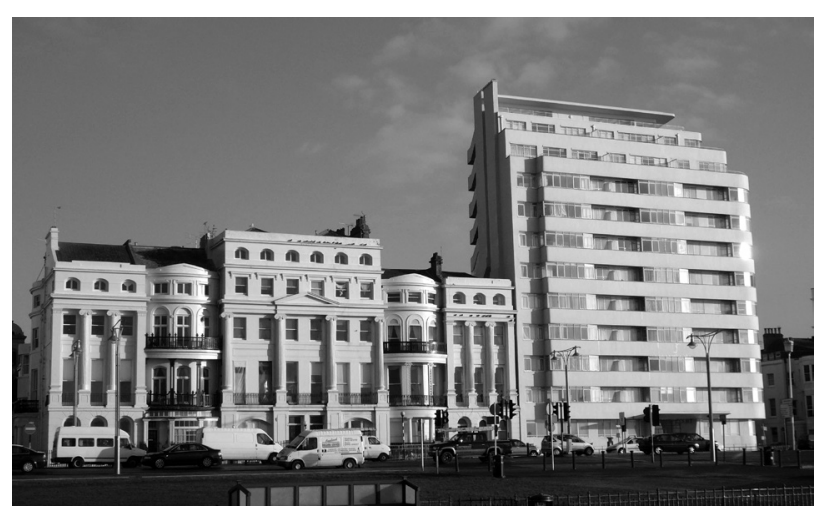

Figure 6

Brighton, England. An apartment block from the 1930's which ignored its early 19th century context. Both the older buildings and the newer one are now preserved.

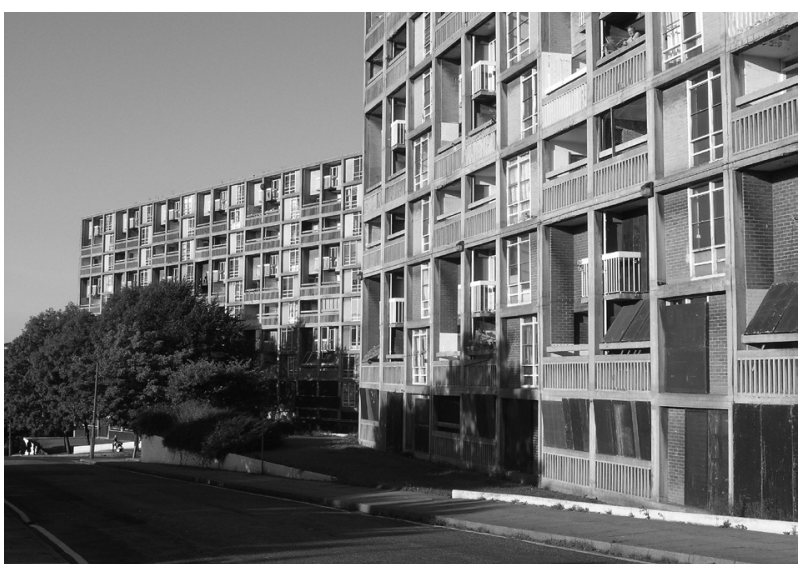

Figure 7

Sheffield, England, The Park Hill flats are now preserved as icons of mid 20th century housing design even though they are loathed by their residents. 


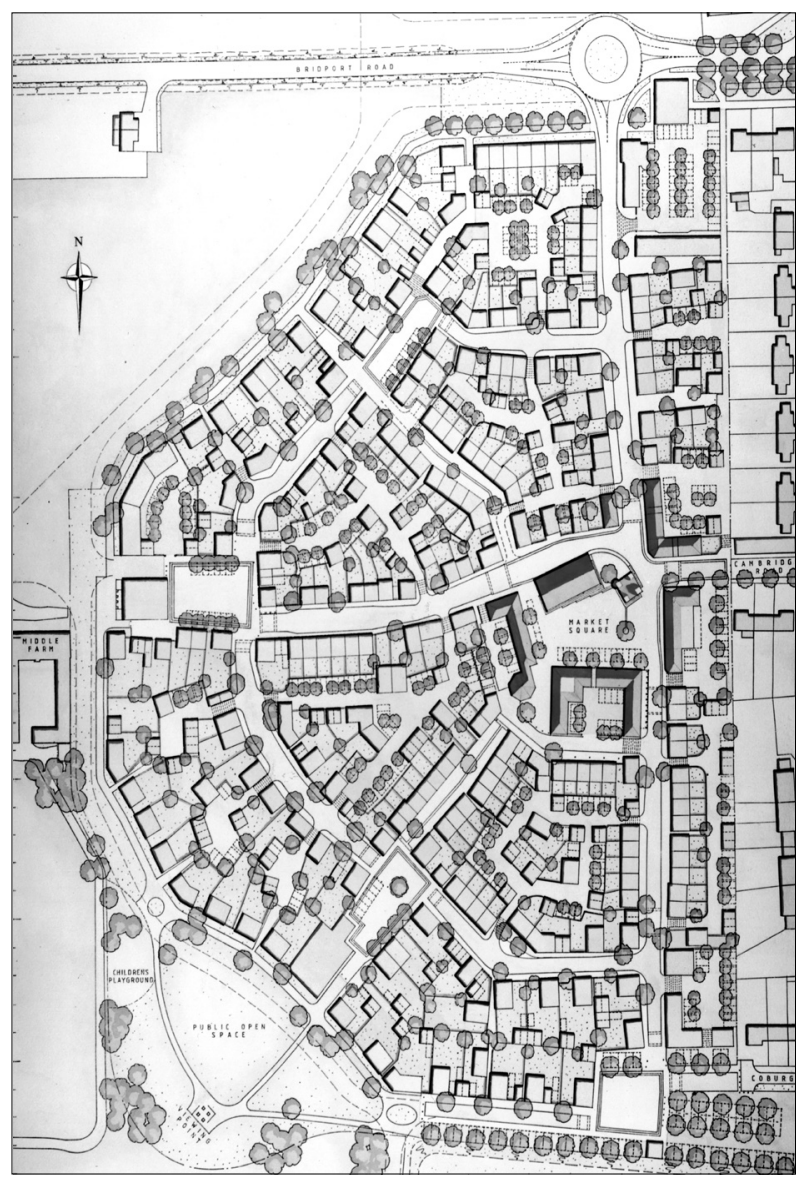

Figure 8

Dorchester, England. Poundbury where new housing built under the patronage of the Prince of Wales attempts to recreate the qualities of the traditional small town.

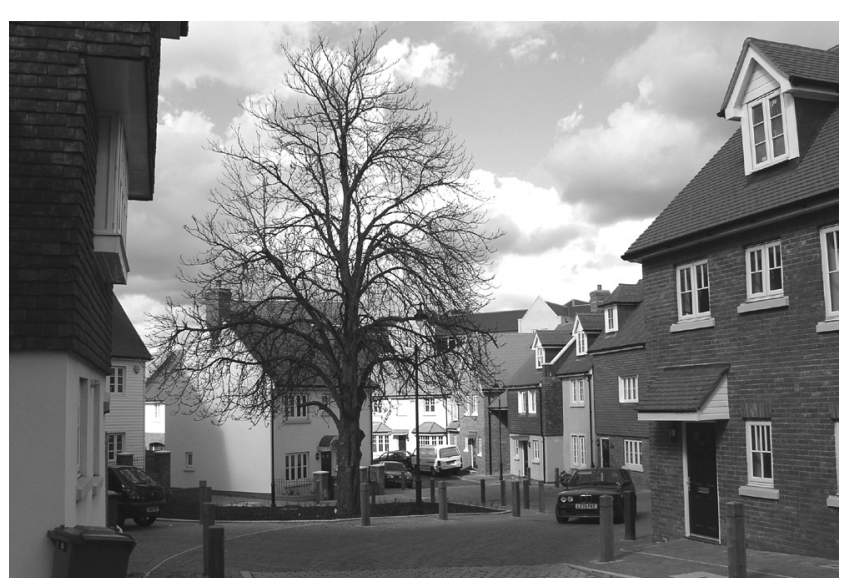

was started in 1993 and is continuing to be built (Figure 8). It has been enormously influential since it seems to have struck a cord with house buyers. Such speculative housing schemes include Ingress Park, a sort of English version of New Urbanism (Figure 9). A recent survey confirmed that $80 \%$ of potential house buyers want a traditional home - but with modern comforts. While the majority of ordinary buildings fit in this mold, special buildings are pushing back the boundaries of design innovation (Samuels 2005). This is as it should be - the failure of the Modern Movement was to impose its innovations on ordinary buildings. After all, in the Middle Ages it was the special buildings, the Gothic cathedrals, which pushed structural design to its limits. The ordinary houses remained the same for centuries.

\section{References}

Action for Market Towns. 1998. Market Towns - Options for the future. Bury St Edmunds, AMT.

Couch, C. 1990. Urban Renewal: Theory and Practice. London, Macmillan.

ODPM (Office of the Deputy Prime Minister). 2005. Planning for Town Centres. London, HMSO.

Samuels, I. 2005. What homebuyers want: Attitudes and decision making among consumers. London, CABE.

Sheffield City Council. 2005. "Regenerating Parkhill". Retrived from www.sheffield.gov.uk/planning

Schafer, R. 1999. IBA Emscher Park. Topes Volume 26. Munich, Callwey.

\section{Figure 9}

London, England. Ingress Park,

a recent development on the edge of the metropolitan area of London which clearly has been influenced by the success of Poundbury in creating a "traditional" quarter. 